Article

\title{
A Study on the Sustainability of the Traditional Sirinić Houses in the Šar Mountain Region, the South-Western Balkans
}

\author{
Saja Kosanović *, Branislav Folić, Stefan Kovačević, Ivana Nikolić and Ljubiša Folić \\ Department for Architecture, Faculty of Technical Sciences, University of Priština in Kosovska Mitrovica, Kneza \\ Miloša Street 7, 38220 Kosovska Mitrovica, Serbia \\ * Correspondence: saja.kosanovic@pr.ac.rs
}

Received: 23 July 2019; Accepted: 25 August 2019; Published: 29 August 2019

\begin{abstract}
The research of traditional rural architecture in developing regions is important to both the preservation of cultural heritage and the mitigation of the trends and consequences of unsustainable rural shifts. In the Western Balkans, for example, negative transformation of the rural environment happens more rapidly than the recording of its traditional built assets. For that reason, the objectives of the present research were to explore general and specific (sustainability-related) characteristics of traditional rural houses in the so far insufficiently studied microregion of the Western Balkans of Sirinićka Župa (Sirinić), to reveal their values and to initiate discussion of the role of heritage regeneration in sustainable rural development. Study has shown that the most significant values of Sirinić houses include opulent spatial-functional typology, distinct architectural expression, and sustainability-related quality in terms of applied materials, structural systems, and multipurpose techniques and elements, as well as a high level of spatial comfort. A necessary regeneration of the traditional houses of Sirinićka Župa must be formulated in a way that enables preservation of recognized general values and further improvement of environmental quality and climate resilience. Simultaneously, functional reactivation of traditional houses should be understood as a contribution to the sustainable development of Sirinićka Župa.
\end{abstract}

Keywords: Sirinićka Župa; heritage; rural houses; sustainable design principles; regeneration; functional reactivation; rural sustainability

\section{Introduction}

The preservation of traditional rural architecture is usually not a strategic priority in developing regions. When coupled with aggravating socio-economic circumstances, neglectfulness and a lack of deliberate actions, built rural assets are inevitably endangered. Moreover, degradation of rural buildings often occurs as a part of an overall rural decline. For example, the Western Balkan region is currently faced with extensive negative transformation of its rural settlements, especially in remote areas. This process represents a consequence of poor economic conditions, deruralization, changes in agricultural production, deterioration of infrastructure, and the inadequacy of rural development policies [1-4].

Traditional rural settlements and individual built structures represent an integral component of rural scenery and are increasingly thought to be valuable to the cultural heritage $[5,6]$. The valorization of rural landscape involves both natural and cultural dimensions [7]. However, the two dimensions of the Western Balkans rural landscape, as well as their interrelations, are yet to be incorporated into contemporary studies, policies and practices. Existing dissociation between nature and culture is perhaps best visible in those rural areas that possess exceptional natural values, but have undergone 
either the abovementioned rural decline, despite their natural potential, or the development process that changes attitudes towards cultural traditions, especially in terms of residential architecture.

Generally, traditional rural houses illustrate a diversity of living cultures and practices, building methods, and architectural styles, but, in the Western Balkans, they are insufficiently explored and mainly unprotected structures that await evaluation, recognition and treatment as heritage. Therefore, recording and research of traditional rural houses represent an important need of this region. Additionally, adoption and efficient implementation of heritage strategies could be relevant for landscape protection and conservation [8], as well as overall rural development. Based on presented facts, this research attempts in the first instance to expand understanding of material heritage in the rural Western Balkans by revealing values of the less-known traditional houses. A narrow rural territory of the south part of the Western Balkans, characterized by exceptional natural values and a remarkable collection of traditional houses, namely, the area of Sirinićka Župa in the Šar Mountains (Sirinić in commonly used abbreviated form), has been selected as the case area.

The concept of sustainability encompasses different spatial levels and domains of human activity. In the architectural sphere, the notion of sustainability mainly refers to the environmental quality of buildings [9]. Studies of traditional architecture at regional and local levels generate knowledge [10,11] about bioclimatic and other environmental principles of design, construction and (re)use [12-17], and provide a valuable baseline for future handling. Nevertheless, when regarded as cultural heritage [18], traditional residential architecture plays a role in the achievement of sustainable development. Finally, sustainability of communities, built settlements and structures depends on economic conditions. For that reason, contemporary studies of architectural heritage should concurrently deal with the different aspects of sustainability, and such an approach was developed and implemented in the research of traditional houses of Sirinićka Župa in the present study.

Initially, the work considered the spatial-social-cultural context in which traditional Sirinić houses were nested. Then, architectural characteristics of 20 selected Sirinić houses were explored, and their fundamental values identified and explained. Based on the determined set of environmental criteria, subsequent comparative analysis resulted in the formulation of sustainability-related characteristics. The synthesis of the findings led to the definition of (1) existing general and specific strengths of the traditional Sirinić houses, and (2) measures that could be applied in their regeneration. This paper concludes with a discussion of the correlation between the direction of traditional rural heritage reactivation and the overall sustainability of Sirinićka Župa.

\section{Materials and Methods}

\subsection{Study Area}

The spatial boundaries of the research encompass the northeast part of the Šar Mountains, i.e., the territory of Sirinićka Župa (Sirinić). The Šar Mountains lie almost in the middle of the Balkan Peninsula. Because of its geographical position, the mountain range was historically considered a part of the Catena del Mondo (the Fetter of the World), the continuous relief mass that divides the warm southern Balkan from the cold northern regions [19]. Sirinićka Župa comprises one of the Šar Mountain microregions of exceptional value, together wit Gora and Opolje, Sredačka Župa, and Podgor Prizrenski.

In administrative terms, the area of Sirinićka Župa overlaps to the greatest extent with the territory of the municipality of Štrpce (Figure 1). Župa consists of 16 middle-size rural settlements developed at an altitude of 800-1250 m a.s.l., each with a population of 500-1000 inhabitants. The administrative and cultural center of Sirinić, and the center of the municipality, is the town Štrpce. 

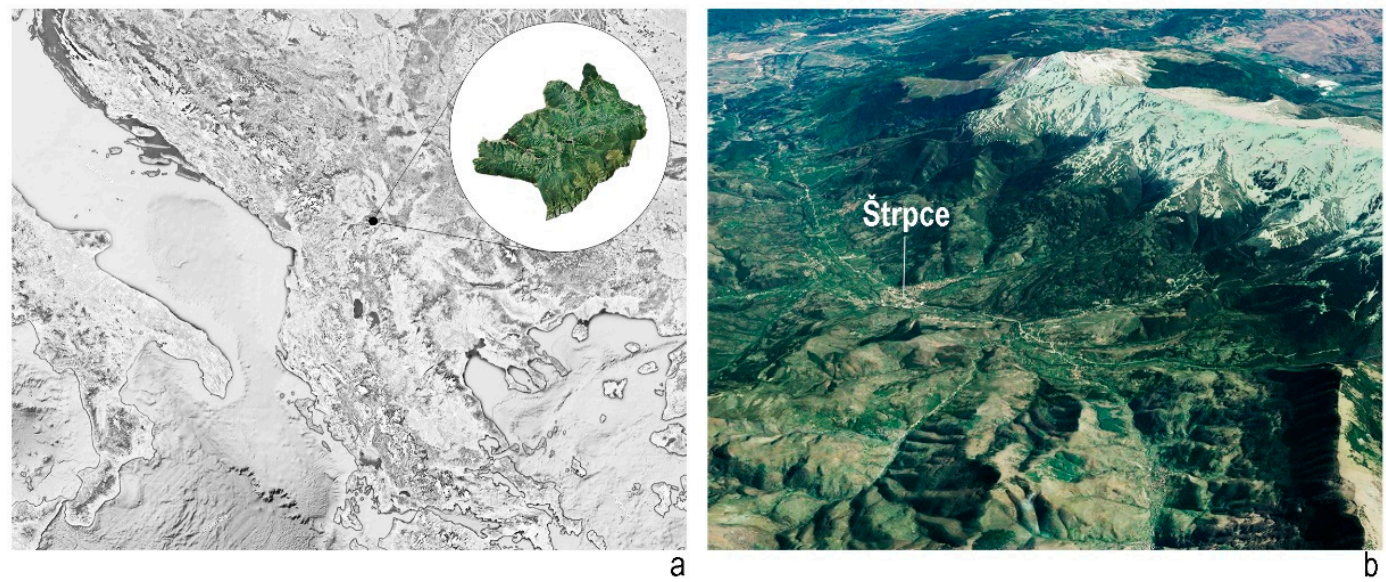

Figure 1. (a) Position of Sirinićka Župa (the municipality of Štrpce) in the geographical context of the Balkan Peninsula; (b) 3D representation of the position of Sirinićka Župa and its center Štrpce in relation to the Šar Mountains. Source: Google Earth.

Based on its altitude, Sirinićka Župa could be categorized as a mountain territory (Figure 2). Nevertheless, several natural factors-such as the orientation of the mountain slopes, the inlet of the warm Aegean climate over the riverbed of Lepenac, and decreased exposure to wind-jointly generate a specific microclimate characterized by long and relatively mild winters, and warm summers. For this reason, the climate of Sirinić is described as župska klima (a variant between moderate-continental and mountain climate) and the whole area is named Sirinićka Župa.
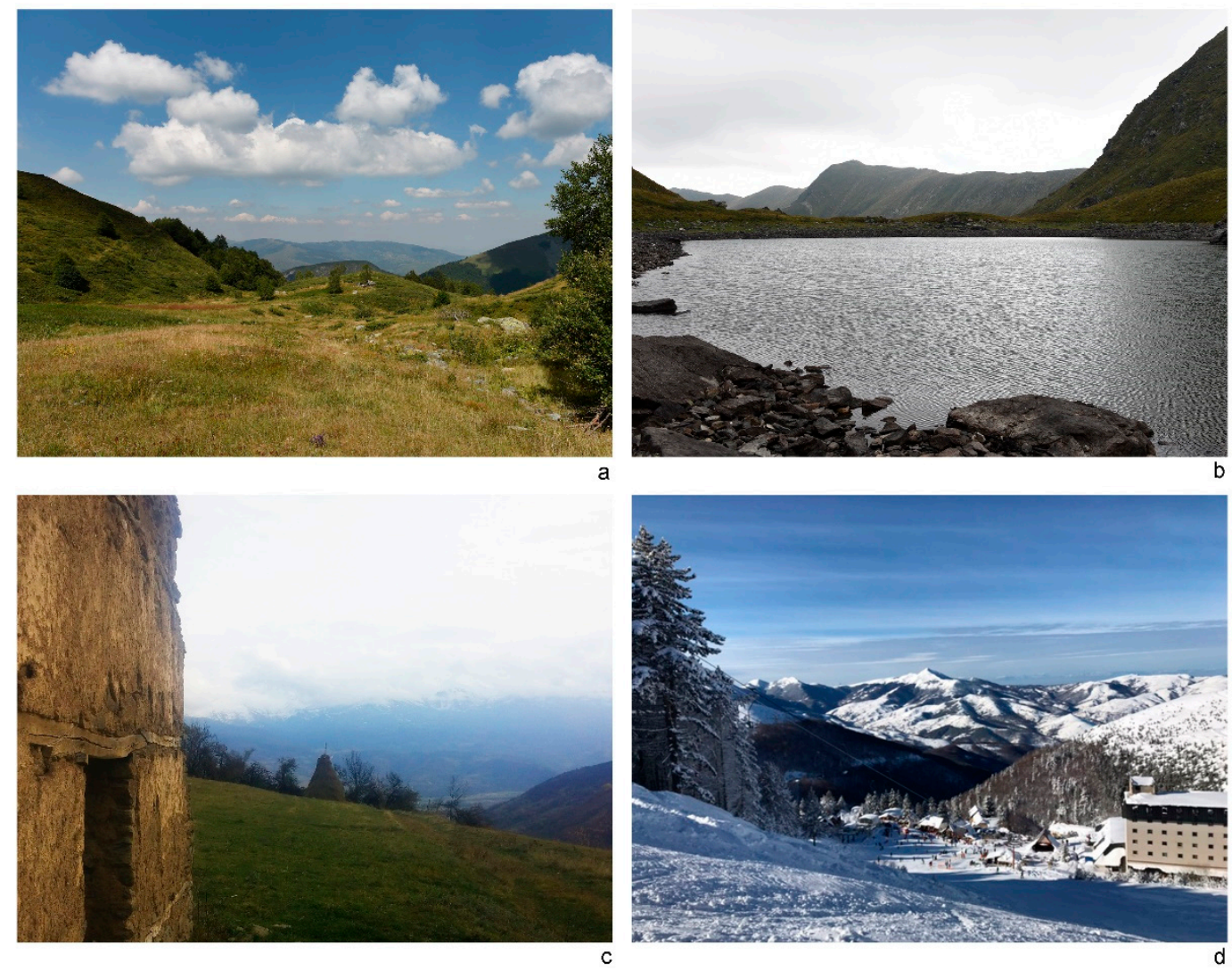

Figure 2. Natural values and the landscape of Sirinićka Župa: (a) meadow vegetation cover; (b) natural lake, 'the eyes of the mountain'; (c) a high-altitude pasture site; (d) the ski area Brezovica. 
Natural values of Sirinić are abundant and exceptional (Figure 2). Part of its territory belongs to the Šar Mountains National Park, one of the richest natural areas in Europe registered in different international lists of nature conservation and protection. The ski center Brezovica, one of the best-known ski resorts in ex-Yugoslavia and south-east Europe, spreads over the most elevated parts of Sirinićka Župa (Figure 2d). Skiing paths and tremendous natural values make Sirinić a popular visiting destination during all seasons. Accordingly, tourism is a key driver of the local economy. Other non-agricultural activities in Sirinićka Župa include trade, private businesses, and work in educational, healthcare, and governance public institutions. Once-vital agricultural activities, such as crop growing or animal breeding, have declined and been substituted with lighter production predominantly organized at the household level.

\subsection{Cultural Development of Sirinićka Župa}

According to historical records, the Hittites were the first ancient people to populate Sirinićka Župa [20]. Several discovered artefacts from the Iron Age and a grave from the Bronze Age [21] chronologically correspond to the period of their civilization. In the Old Age, an important interregional transport corridor-the so-called Old Prizren Road—was built over the Sirinić territory. In the 4th century AD, two or three town fortifications were erected along this road, and the remains of one are found in Sirinić.

Sirinićka Župa was first referenced in the 13th-century document Srpsko Jevanđelje (the Serbian Gospel). In the document Povelja kralja Dušana (the Charter of the Serbian Emperor Dušan), written in 1322, Sirinićka Župa was described as metoh (the property) of the Monastery Hilandar. Later Ottoman statistical records mention Sirinić villages in the linguistic form that corresponds to their present names [22]. During the 16th century, a significant number of local Sirinić churches were (re)built, most likely a collective reaction to the renewal of the UNESCO monastery Pećka Patrijaršija.

Exploitation of chromite mineral, initiated at the transition from the 19th to the 20th centuries, instigated the modern development of Sirinić. Consequently, the image of some settlements, especially of the center Štrpce, began to transform from typical rural (productive) to non-agricultural. During the 1960s, another major economic shift occurred due to the closure of mines and the initiated development of tourism [22]. Introduction of new spatial forms, such as hotels and weekend houses, and application of modern methods in new house construction caused the abandonment of traditional building. The trend of negative transformation of Sirinić landscape continues until today.

In addition to the ancient and medieval heritage, the material cultural legacy of Sirinićka Župa encompasses cemeteries and monuments from World Wars I and II. However, the most expressive tangible heritage in this microregion are the traditional single-family houses built from the second half of the 19th century until World War II.

Although not protected, and to a large extent abandoned, constructions of stara kuća (the old house- - the term used by local inhabitants to depict a dwelling structure built before World War II) are still common in the settlements of Sirinićka Župa, primarily because of their applied construction systems and the materials that provided structural longevity (Figure 3). The municipality of Štrpce estimates that at least one hundred traditional houses still exist in Sirinićka Župa, but their exact number is not registered. Field study indicates that some of the Sirinić houses have been renovated. For the most part, interventions concern façade refurbishment, replacement of windows and roof tiles, and the insertion of service systems. Even though the original spatial organization has been preserved in most cases, the renewal of traditional Sirinić houses is not based on traditional design and construction methods. 

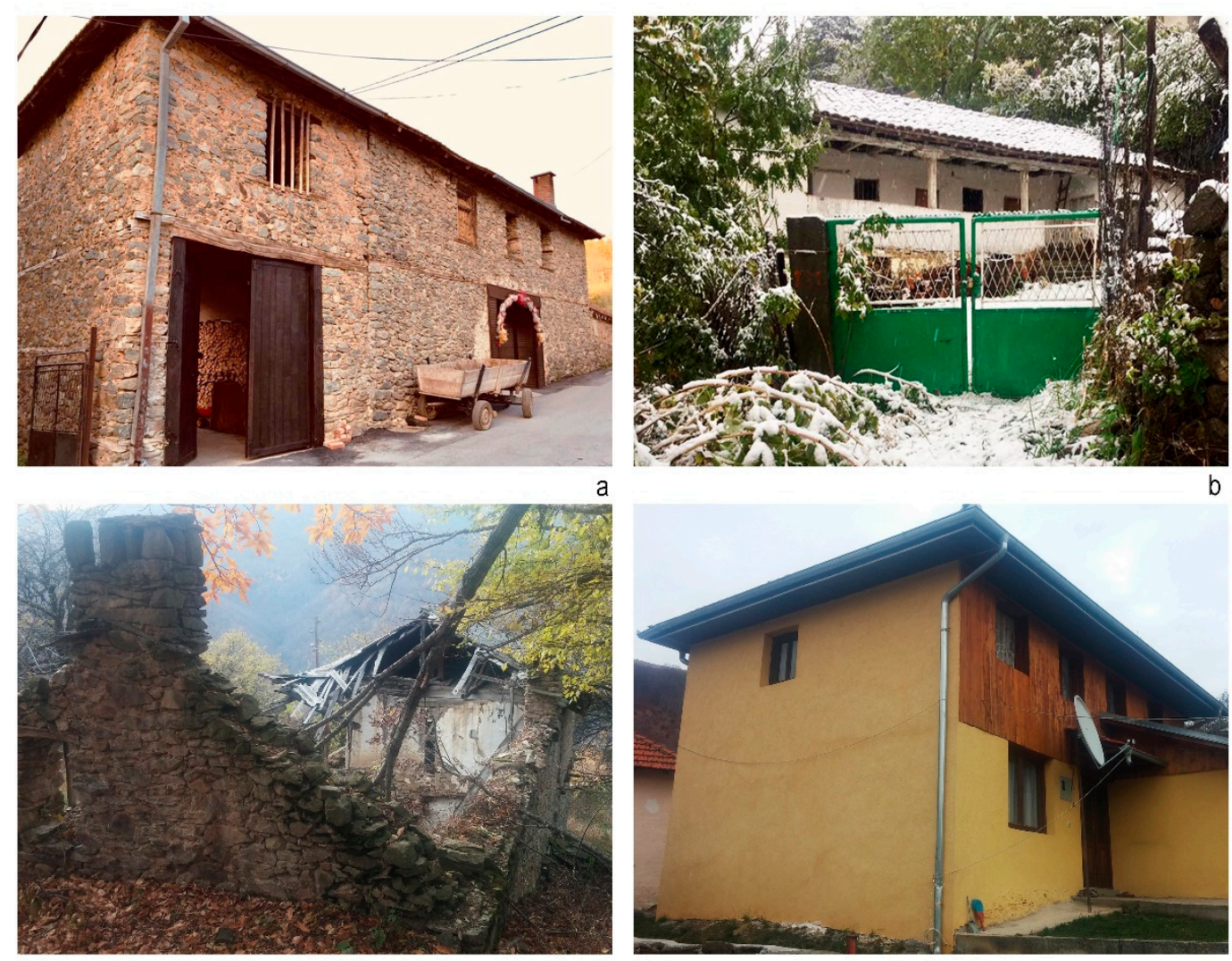

Figure 3. (a,b) Examples of traditional Sirinić houses in use; (c) devastated structure; (d) an example of house renewal.

\subsection{Research Methodology}

The present research topic was conceptualized based on the identification of a realistic research gap, on the one hand, and the relevance of the research field confirmed by reviewing the body of published literature, on the other. The research process started with a preliminary field study and the formulation of the research aim, structure, and methodology.

During the first field visit, 20 examples of traditional Sirinić houses constructed between 1870 and 1935 were mapped as the cases to be explored. The houses are located in the following villages of Sirinićka Župa: Berevce, Vrbešnica, Sušiće, Gornja Bitinja and Sevce, as well as in the central settlement of Štrpce. Their selection was based on accessibility to house structure, preserved original characteristics and distinctiveness in relation to other houses built during the same period. According to the use status, the chosen Sirinić houses fall into three groups: houses that still have a residential purpose, houses used as an auxiliary/storage space, and abandoned houses.

General and sustainability-related characteristics of traditional houses in Sirinićka Župa were explored using several shared research methods, such as a literature review, in situ measurements, recordings and interviews with local builders and house owners on multiple occasions from September 2018 to May 2019, and the comparative analysis of collected material.

Conversations with local builders and house owners helped to understand and subsequently to describe the impact of traditional lifestyle on the design of Sirinić houses, as well as the methods applied in their construction.

The size of the sample allowed for the development of typology of Sirinic houses, while the identification of similarities enabled the formulation and description of their common characteristics.

In addition, the study of sustainability-related quality of the existing Sirinić houses was underpinned by a set of criteria derived from the contemporary understanding of an environmentally 
sustainable building and its hierarchical structure, namely, passive and active mechanisms, the physical framework and the indoor environment $[9,23]$ (Table 1). Having in mind that the research dealt with traditional built structures, the categories Physical Framework, Passive Mechanisms, and Indoor Environment were taken as a backbone of the study of the actual state, while the potential application of active mechanisms was considered in the context of future regeneration-related interventions.

Table 1. Categories and criteria applied to the study of environmental sustainability of traditional houses in Sirinićka Župa [23].

\begin{tabular}{llll}
\hline \multicolumn{1}{c}{ Physical Framework } & \multicolumn{1}{c}{ Passive Mechanisms } & Indoor Environment & Active Mechanisms \\
\hline Materials & Passive heating & Spatial organization & Electricity generation \\
Structure & Passive cooling & Spatial comfort & Solar collectors \\
Envelope & Natural ventilation & Indoor air quality & Geothermal pumps \\
Finishes & Daylighting & Thermal comfort & Active heat recovery \\
Services/Conditioning & Alternative water sources & Light comfort & Active lighting \\
Equipment & Water recycling & Visual comfort & Intelligent systems \\
& Passive water heating & & \\
& Greening & & \\
& Earth sheltering & & \\
\hline
\end{tabular}

\section{Results}

\subsection{Architecture of Traditional Sirinić Houses}

The settlements of Sirinićka Župa were developed in places with optimal natural characteristics and large potential for agricultural production. Therefore, different historical layers of settlements' evolution and revival can be identified at a single location [24].

The existing rural structure of Sirinić villages dates to the 19th century. Its essential characteristics are irregular street pattern, modeled according to the relief, and dense construction that reflects rational land use and the patriarchal organization of local rural communities [25]. The street matrix is organized hierarchically, from access roads towards individual households to the main communication that connects all villages in Župa. Street geometry, division of agricultural land, and terrain characteristics dictated the form and the size of the plots and generated multivariate street-plot-house relationships. The position of the houses ranges from frontal-on a street line to the center-in the middle of a parcel, to a corner at the angle of a parcel framed by streets from two adjacent sides. In such circumstances, spatial relations between the neighboring houses in a same settlement are also unsteady.

The origin of traditional houses of Sirinićka Župa can be explored in the wider contexts of Balkan, eastern Mediterranean, Ottoman, and Byzantine architecture. During the 19th century, however, the house of Sirinić has evolved into a distinctive architectural form with local specificities [26]. The architecture of Sirinić houses built from the second half of the 19th century is a product of a particular combination of several chief determinants: spatial organization, applied building materials and structural systems, and two porch-like elements. Because of the uniform design formula, traditional houses of Sirinićka Župa have a lot in common. On the other hand, each house displays individual adjustments to the micro-sociological and micro-spatial contexts. Therefore, each of the studied traditional houses is unique.

Comparative analysis of the selected examples points to flexible spatial organization of the Sirinić houses. Based on the vertical distribution of space, two basic typologies can be distinguished: single-story and two-story houses. The vast majority of traditional houses in the landscape of Sirinićka Župa are two-story structures. Vertical spatial arrangement is considered an optimal way to adjust to the sloped terrain and to functionally respond to the way of life and the primary household activity. Horizontal spatial complexity grows based on the principle of linear addition of rooms. Consequently, a house plan most often has the shape of an elongated rectangle with a width range of 6-8 $\mathrm{m}$ (Figure 4). 
$[\bar{j}]$
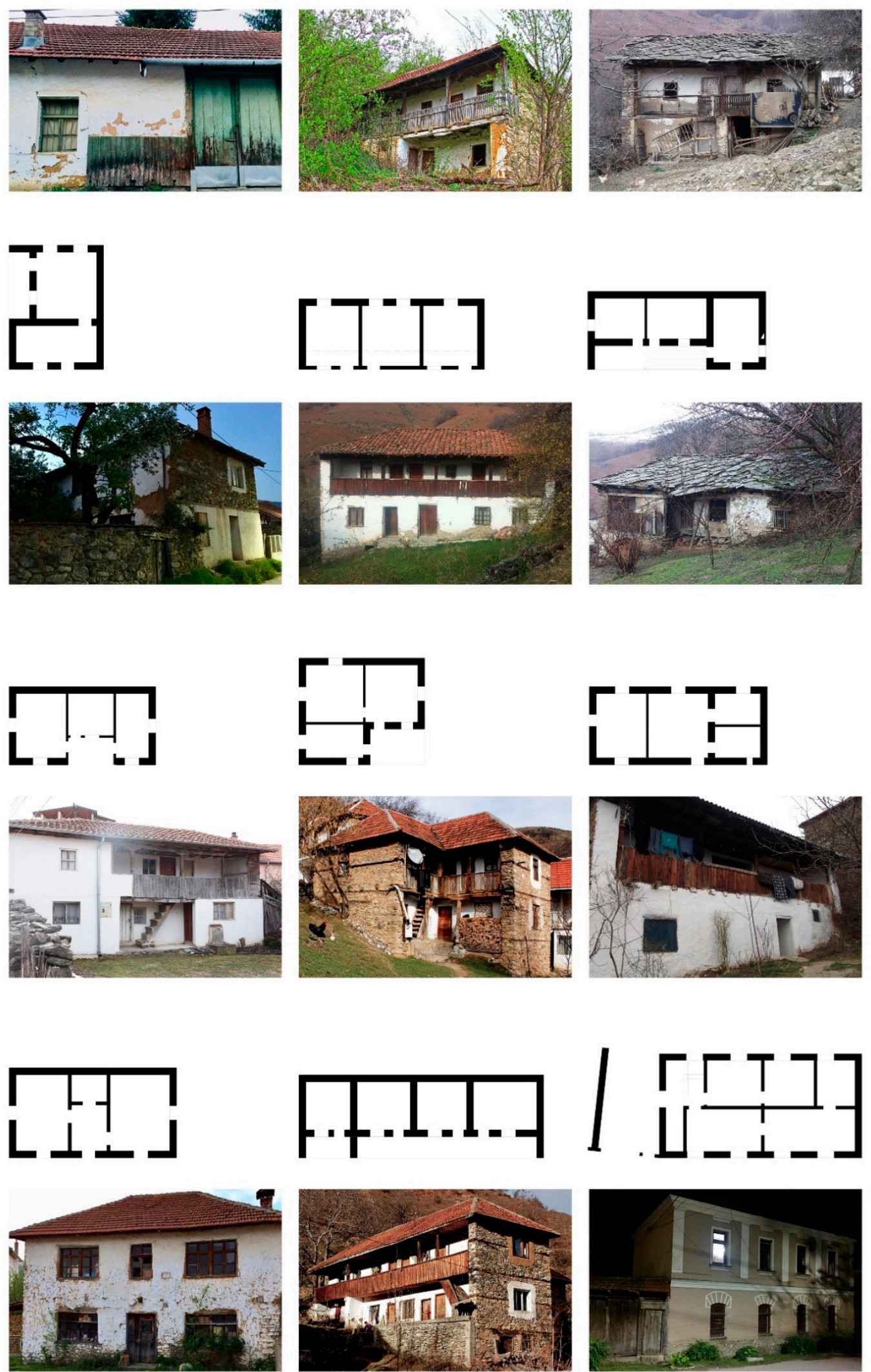

Figure 4. Typology of Sirinić houses based on horizontal plan development. 
The volume of Sirinić houses and the number and function of encompassed rooms were rather conditioned by family size and structure than by its socio-economic status. The simplest single-story houses comprise two rooms, one of which was used as central residential room (the so-called kuća) and another as an auxiliary space. The most complex two-story variants feature kuća, one or two rooms for common household activities, storage, and even the animal stable in the lower story, as well as bedrooms, living room and occasionally animal food storage in the upper story.

Inner corridors and closed staircases are rarely found in traditional Sirinić houses. Instead, all in-house communications as well as the entrance zone were enabled by introducing the porch-like elements in most cases. The semi-opened communication space embedded in the ground story is called the ajat, while the čardak is found at the front section of the upper story [26]. Orthogonal bases of traditional ajat and čardak range from a variably elongated rectangle to " $\mathrm{L}$ " or " $\mathrm{U}$ " shapes. The position of these spaces in the house plan is either central or angular (Figures 4-9). When generational family division or increased household size created a need for additional living space, the two porches would be closed at their longitudinal ends to obtain new rooms.

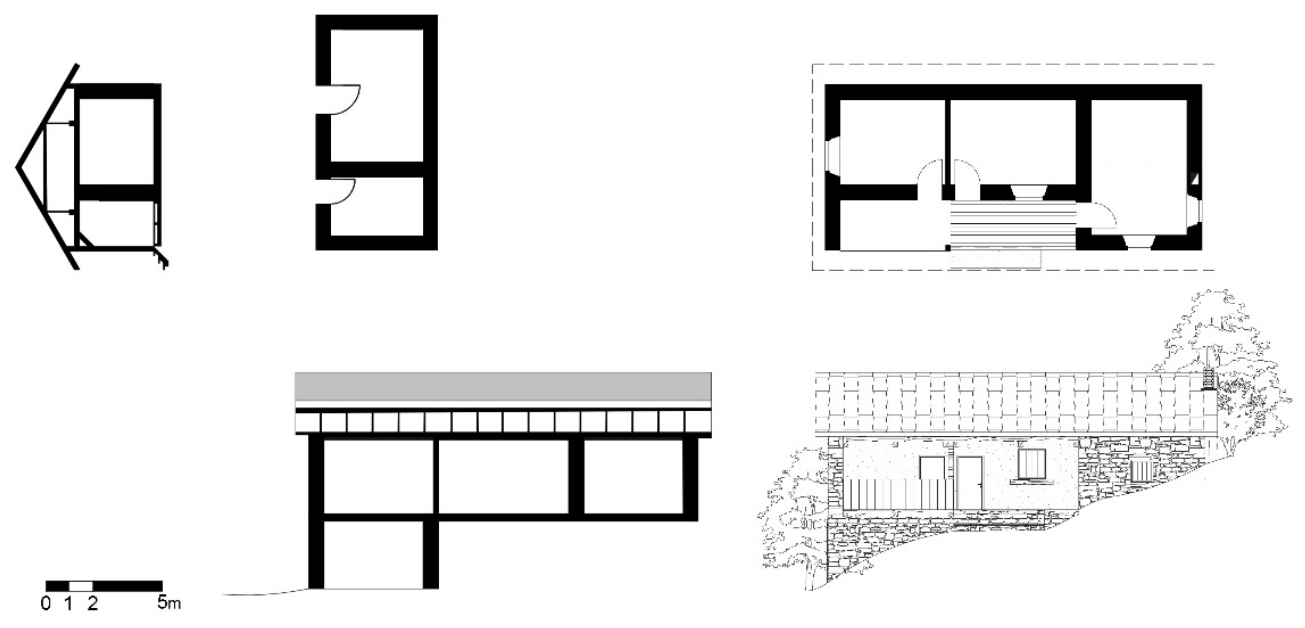

Figure 5. House of Stanišić family, Sušiće, 1871-75.
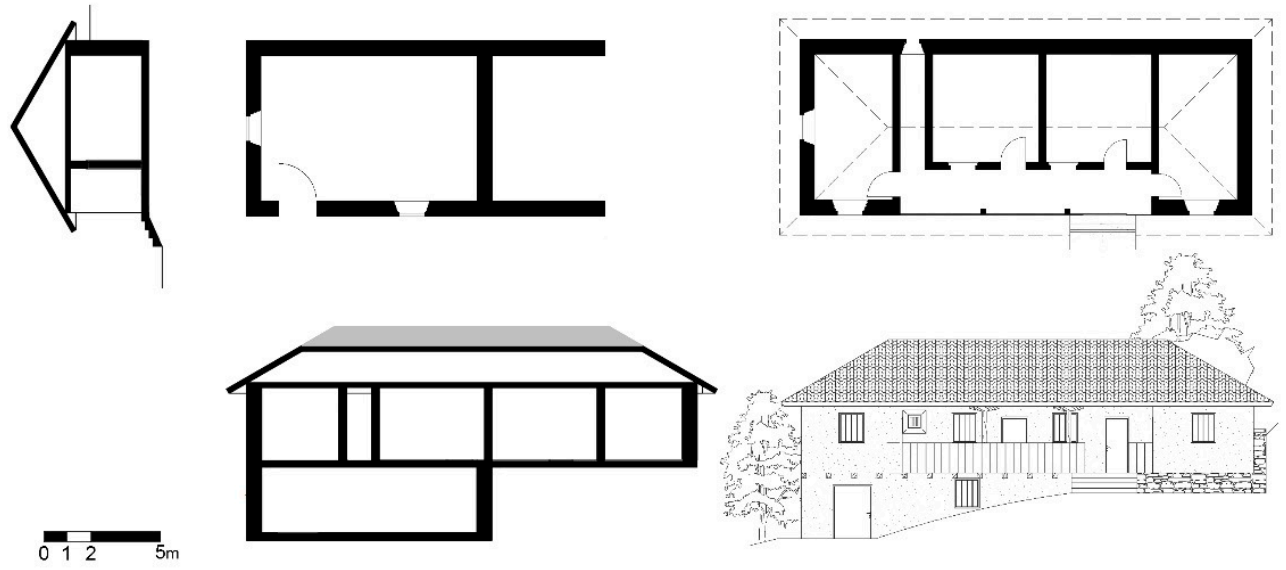

Figure 6. House of Nikolčević family, Štrpce, 1901. 

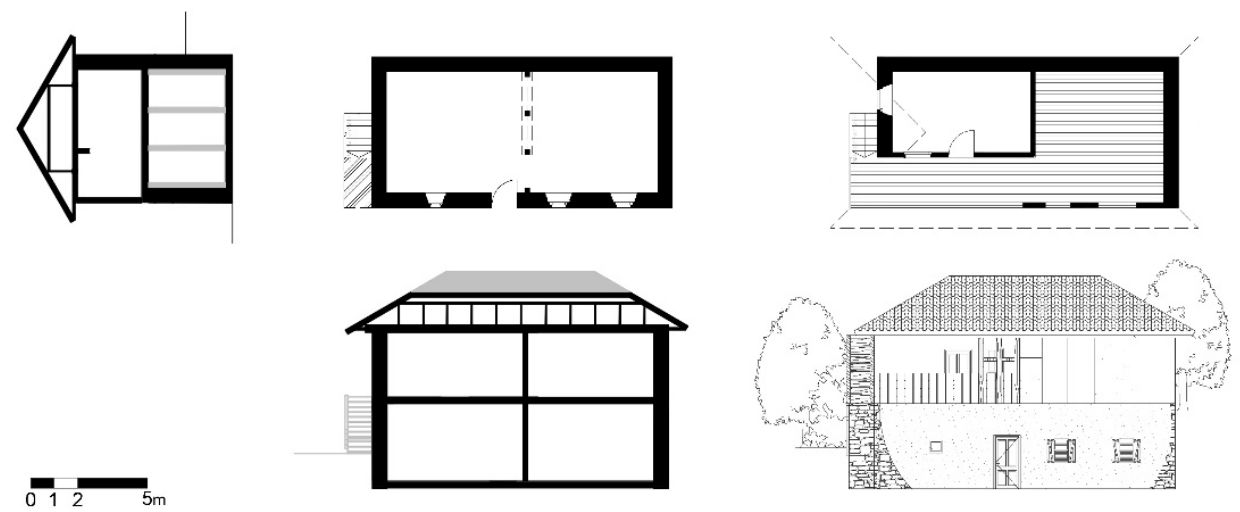

Figure 7. House of Nikolić family, Gornja Bitinja, 1895.
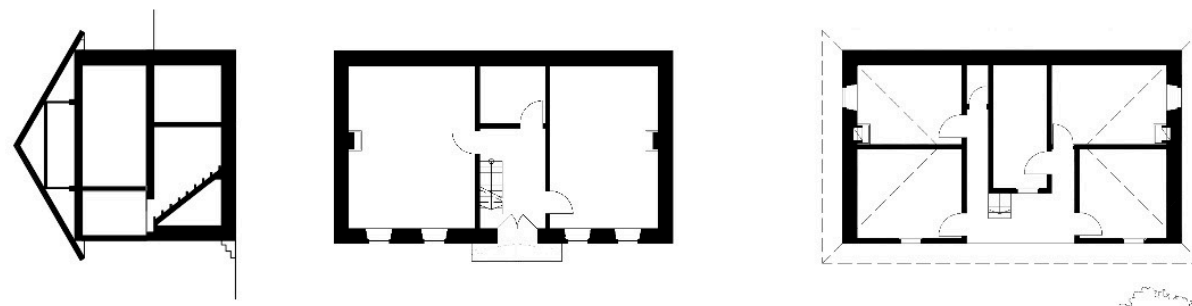

$0125 \mathrm{~m}$
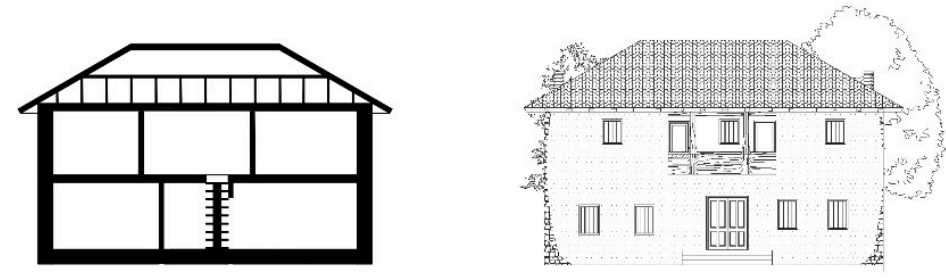

Figure 8. House of Mladenović - Kovačević family, Berevce, 1924.
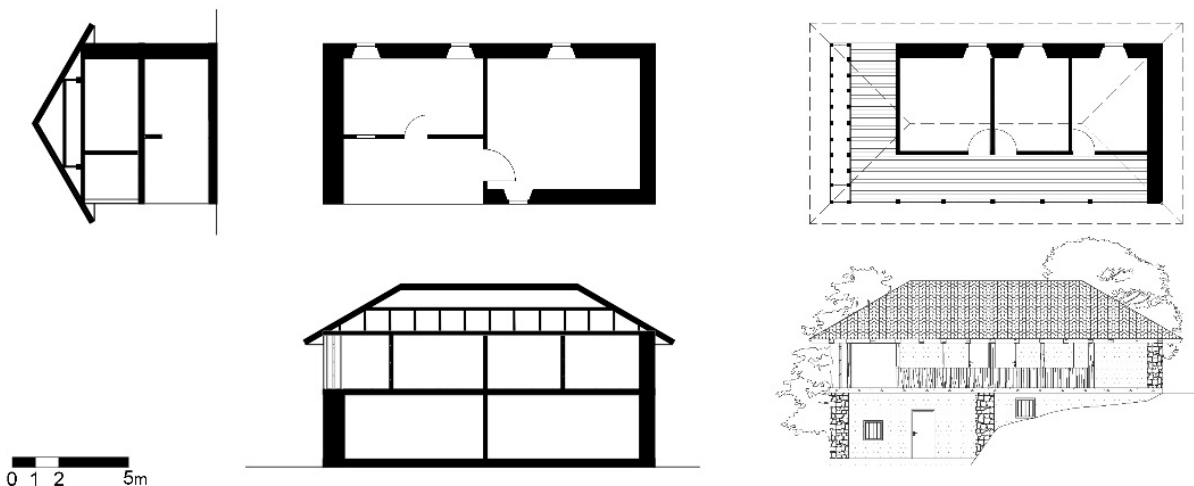

Figure 9. House of Kecić family, Štrpce, 1913.

Two spatial, designing, transitional, multifunctional and focal elements-ajat and čardak-interrupt the otherwise compact house form. The definition of their relationship towards the front façade and the overall house volume make up a principal task in the traditional design. Accomplished spatial and visual prominence of ajat and čardak assign to traditional Sirinić houses an exclusive appearance which is neither strictly rural nor typically mountain-like. Accordingly, the main attributes of traditional architecture in Sirinićka Župa are elegance, purity, and the visual harmony established through symmetry or asymmetrical balance. 


\subsection{Physical Framework}

\subsubsection{Materials}

The so-called Lepenački kamen-hard natural stone taken from the nearby river Lepenac-is one of the basic materials used in construction of traditional Sirinic houses. The extracted stone would be minimally reshaped at the construction site. Together with the applied construction system, the good quality and resilience of Lepenački kamen explains the durability of Sirinić houses. Stone utilization was also significant from the perspective of earthquake protection, considering that the area of Sirinićka Župa represents a seismically active terrain with a history of earthquakes and the possibility for catastrophic events. Finally, because of its thermal properties, the stone was considered the optimal choice for year-round stabilization of indoor temperatures.

Foundations and sustaining walls on residential plots were often constructed with previously used stone. However, the most notable local examples of stone reuse are Sirinić churches (e.g., the 13th-century church Sveta Petka) that were rebuilt on new sites by replicating the original form and using the original material.

Another natural and locally abundant building material used in the construction of traditional Sirinić houses was wood. Intensive application of this material corresponded to a wide range of constructive demands, roles, and purposes, from skeleton structure, to stiffening elements, to cladding, to the structure of roofs, staircases, and ajat and čardak (Section 3.2.2). Structural timber elements were usually made of beech, while walnut and cherry wood were used in the manufacture of doors and window frames. To protect the exposed timber and to enhance its longevity, traditional builders were applying techniques, such as smoking on fire or coating with a resin of plant origin.

Equally widespread as stone and wood was the utilization of earth material. A moist mixture made of earth, straw, and occasionally other added organic matter was used to fill in the lightweight walls and floor/ceiling constructions. It was also used for surface covering and plastering. Earth with a high content of clay was used to manufacture the so-called cerpič wall bricks or ćeramida roofing tiles. Here, earth was first blended with straw, and the produced admixture subsequently molded and sun-dried. Ćerpič and ćeramida were also commonly used in traditional architecture of other parts of the Balkans.

\subsubsection{Structure and Envelope}

Traditional houses of Sirinićka Župa feature a structural composition made of a combination of two types of construction systems. The first basic type is characterized by massive walls made of stone (Figure 10a). The second, lightweight bondruk, is composed of timber framing and a filling either from (1) stone or ćerpič bricks, or (2) moist mud-and-straw mixture inserted into interspaces between planks previously banded with structural timber frames (Figure 10b,e). Various combinations of these two types of constructions are found in the field. Actual application primarily depended on location characteristics, planned house size, and the presence of ajat and čardak. Houses with a larger number of rooms and two stories are characterized by massive U-shaped exterior stone walls and the bondruk front façade wall. Because of the presence of ajat and čardak, the wall of the front façade is indented. Inner vertical partitions were either made of stone or bondruk timber frames.

The thickness of exterior stone walls normally ranges between 50 and $70 \mathrm{~cm}$, and even reaches $100 \mathrm{~cm}$ at the position of the earth-sheltered basement, i.e., the lower story. Partition stone walls are thinner, from 20 to $30 \mathrm{~cm}$. Timber lacing was used for stiffening and levelling. Larger stone wall surfaces were stiffened by additional timber beam-like elements. The most common binder type used in the construction of stone walls was mud, whereas lime mortar was only occasionally applied. The use of binders in wall construction was preceded by suvozid (dry-wall) masonry technique. The remains of the suvozid construction method in the area of Sirinićka Župa are still present.

Typical floor/ceiling construction consists of parallel timber beams placed at distance of 50-100 cm and transversal stiffening beam-like timber elements of comparably smaller cross-sectional dimensions. 
The interspace between the beams was filled with a lightweight insulation mixture composed of reed, earth, and straw material.

Timber staircases with steep stairs are often found in semi-open ajat and čardak. In fact, the complete structure of these two elements is made of timber. The exposed structure of ajat and čardak and the presence of free-standing timber columns greatly influenced the overall house appearance.

A timber structure placed at an angle of $25-30^{\circ}$ forms either a gable or hip roof. Roofs of the 19th-century Sirinić houses were covered with stone tiles. Clay roofing elements were introduced later, when their manufacture was sufficiently mastered (Figure 10c).
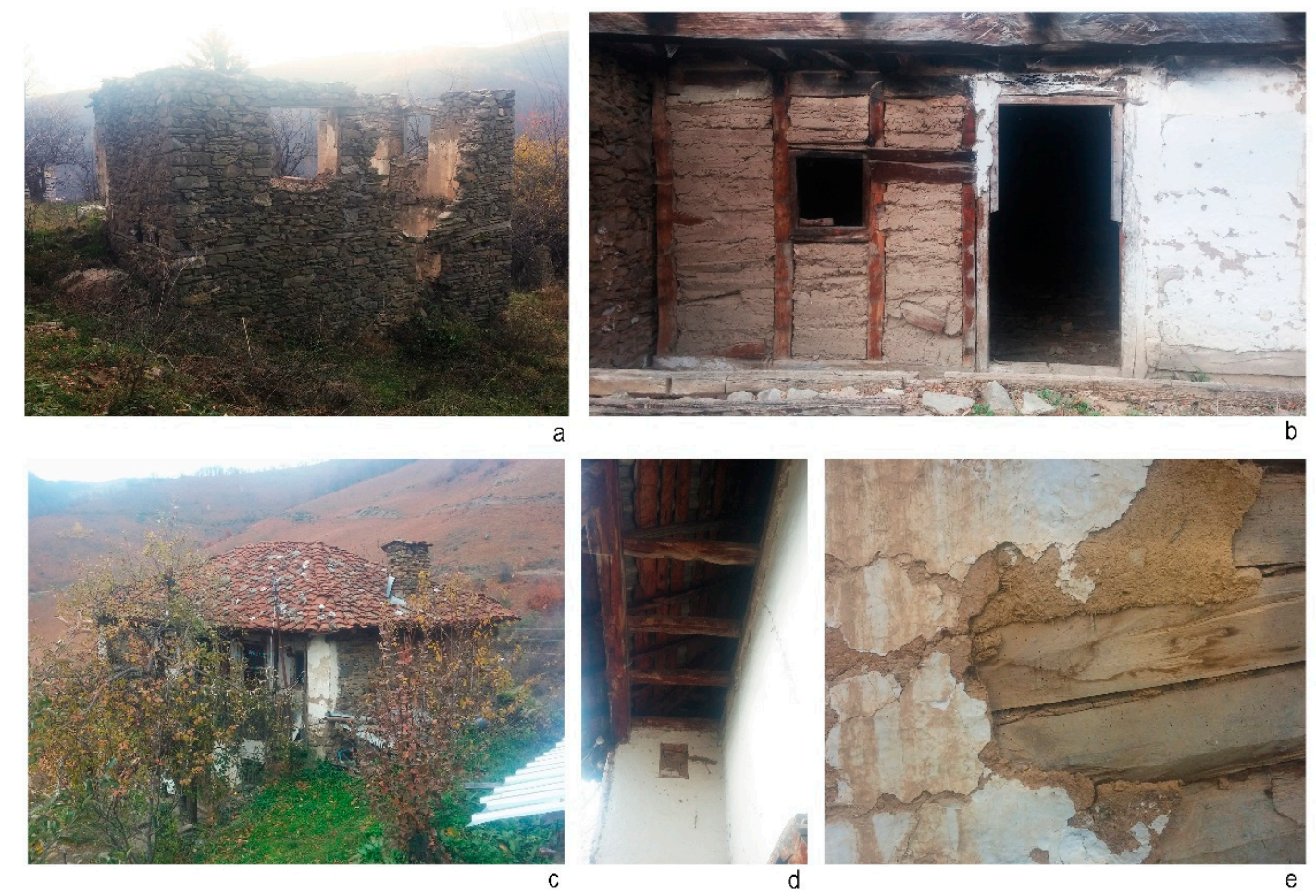

Figure 10. Structures and components of Sirinić houses: (a) remains of exterior stone walls of a two-story house; (b) bondruk structure; (c) original ćeramida roof tiles; (d) roof eave structure; (e) covering of bondruk wall with a mixture of mud and straw.

\subsubsection{Finishing Surfaces}

Exterior and interior wall surfaces of the traditional houses in Sirinićka Župa were covered either with the mixture of mud and straw or the lime mortar.

The floor laid on ground was mostly made of rammed earth, and in some case of stone tiles. The upper-story floor cover consists of timber planks placed over a horizontal loadbearing construction. In older existing examples of Sirinić houses, the timber roof structure was mounted straight above the residential space. In time, the underroof space became separated from the living area; an introduced barrier was materialized either as a thin construction made of timber slats and reeds, or a full-scale floor/ceiling construction. In the latter case, timber planks were fixed to the ceiling side of the primary construction and occasionally covered with mud or lime mortar.

Exterior and interior wall surfaces and the ceilings were painted with lime (calcium hydroxide).

\subsubsection{Services}

Fresh water was originally provided from household wells or nearby running water sources. In most cases, the only water supply points were positioned outside of the house. Accordingly, sanitary rooms were constructed as separate timber structures. By the shortest possible lines, black water from 
the field toilets was transported to the river Lepenac or to some of its streams. A major exception to this practice, found in the village Berevce, shows that sanitary rooms equipped with plumbing and sewage systems were introduced into houses at the time of their original construction. Such a luxury of the time was achieved by intelligent use of sloped terrain and the earth sheltering technique. Municipal plumbing and sewage systems were introduced into some traditional houses of Sirinić during the 1960s. Power supply was provided together with the regional electrification at the beginning of the 1950s.

\subsection{Passive Mechanisms}

\subsubsection{Heat Loss and Heating}

Terrain characteristics and the local Sirinić climate were well understood and integrated with traditional passive design techniques at multiple spatial scales, from settlements, to plots, to houses.

Achieved house compactness contributed to the reduction of heat loss during cold seasons. On the other hand, ajat and čardak moderated the temperature of external cold air before it entered the indoor environment. Thick façade walls would first absorb and later release the heat, thereby acting as heat storage. In fact, heat accumulation represents the fundamental passive technique applied to the traditional Sirinić houses.

Thermal insulation was applied sporadically, at only a few thermal envelope positions. In support of the physical separation of heated rooms from the non-heated underroof space, a lightweight insulation mixture composed of reeds, earth, and straw was inserted between the elements of horizontal construction. In other examples, ćerpič walls or ceiling constructions were covered with timber planks.

The size of envelope openings was predefined by the applied structural system and the method of manufacture of timber doors and window frames. Although the preferred orientations were south and east, actual conditions at the plots resulted in variable positions of the windows. Field study indicates that the orientation of Sirinić houses is to a lesser extent a reflection of the goal to achieve direct solar heat gain, and to a greater extent the consequence of the house's relationship towards the existing street matrix, terrain slope, and the overall settlement orientation.

The heating of traditional Sirinić houses was provided by installing wood stoves or manufacturing of open fireplaces. Regardless of the type, individual heat sources could be present in one or several rooms. They were usually positioned at the center of a room to enable efficient heat distribution. The chimneys of open fireplaces were built into the massive façade walls, thus allowing for the use of the waste heat as a secondary source. During the day, the heat was directly generated from burning wood. During the night, the thick stone walls would release previously absorbed heat.

Another way to capture and use the heat was related to functional organization. In some Sirinić houses, domestic cattle were kept in the ground story and the residential rooms were upstairs. The heat radiating from animals would naturally move upwards, and pass through the wooden ceiling, to finally heat the upper indoor space.

\subsubsection{Heat Gain and Passive Cooling}

Master-builders of traditional Sirinić houses did not perceive direct solar radiation as a significant threat to indoor summer thermal comfort. Transparent envelope parts, though modestly dimensioned, originally were not accompanied by solar protection elements. To that end, the primary role of eaves, whose width varies from $30 \mathrm{~cm}$ to even $110 \mathrm{~cm}$, was to protect the exposed parts of house structure from precipitation. Therefore, eave design is not in direct correlation with the orientation. On the other hand, the ceilings above the south-oriented ajat and čardak provide shade and form comfortable spaces for a stay during the warm season. Considering the position in the house plan and the correlation with surrounding individual rooms, an additional benefit of the introduction of ajat and čardak was thermal load reduction.

A traditional lack of concern regarding magnitude and the effects of direct solar radiation can be justified by modest materialization of open rural space, vast greenery in the surroundings, and 
the significant variations between day and night summer temperatures. Massive house structures and applied materials together provide effective temperature stabilization as they postpone heat radiation and protect the indoor space from overheating during warm summer days. In some positions, passive cooling during the night was enhanced with a cross-ventilation effect. Another measure that contributed to the indoor temperature regulation was earth sheltering.

\subsubsection{Earth Sheltering}

The amalgamation of traditional Sirinić houses with the terrain allowed for the establishment of direct contact between earth and the vertical envelope. Most of the traditional houses in Sirinićka Župa are partially earth-sheltered. Sloping terrain and the thermal inertia of earth were so combined to prevent both winter heat losses and summer heat gains. The result was stabilized indoor temperatures in those rooms that were not heated and that served as food storage throughout the year.

\subsection{Indoor Environment}

The houses of Sirinićka Župa feature rational and flexible spatial organization reflecting the lifestyle of rural inhabitants and their changing needs over time. Large surfaces of the rooms and their untypical heights of 2.6-2.9 m jointly provide very good spatial comfort. Some rooms, as well as the semi-opened spaces of ajat and čardak, are multipurpose. Polyfunctionality is best represented by the example of čardak: during warm days, this space was used for work, leisure, dining, laundry drying, and even guest receptions; on summer nights, čardak served as an open-sky dormitory. In-house migrations confirm that the synergy between the applied design principles and the residents' habits had been established.

Sirinić houses are made of materials with good properties in terms of vapor diffusion. In combination with the applied construction methods and good natural ventilation, this means that the living space was capable of good moisture regulation. In addition to aesthetics, lime-based paint on ceilings and walls also had hygienic significance, given the ability of this material to protect from microorganisms and to allow the structure to "breathe". Although individual furnaces and fireplaces were essential for providing the thermal comfort of Sirinić houses, from today's perspective they are regarded as indoor pollution sources.

Visual contact with the surrounding outdoor space was established from all residential rooms. Nevertheless, the analysis of visual comfort in Sirinić houses must be approached more comprehensively by taking into consideration the entire spatial organization, connection with the ground surface, and the traditional lifestyle. For the same reason, the dimensions of window openings should be analyzed from the perspective of the time when they were defined, even though they are insufficient according to today's standards. Similarly, light comfort in the form in which it is known today was not of primary importance originally, considering the large quantity of time which active traditional dwellers spent outside the house, especially during the warm part of a year.

\section{Discussion and Conclusions}

The analysis carried out in this research has shown that the traditional residential architecture of Sirinićka Župa has a valuable material legacy whose importance transcends local boundaries, given its opulent spatial-functional typology and distinct architectural expression. In addition, the research has revealed several sustainable strategies that were applied in the design and construction of traditional Sirinić houses. These strategies can be summarized as follows: use of natural and locally available/produced materials; development of rational, flexible, and durable structural systems; introduction of multipurpose elements, such as earth-sheltered and massive walls, and porch-like ajat and čardak; and the achievement of a high level of spatial comfort extending beyond physical boundaries of a house because of its immediate connection with the surroundings.

Although the acknowledged quality of Sirinić houses does not proclaim novel principles in the context of the traditional environmental design, it well demonstrates how general prescripts can 
be adjusted and applied to a specific case. Perhaps more importantly, the explained environmental quality of traditional houses in Sirinićka Župa represents a relevant starting point for their necessary regeneration.

Field research indicates that such interventions are needed for all 20 studied houses. They must be planned in line with the universal goals to preserve recognized architectural values, respond to present-day requirements, and improve overall ecological quality. To that end, some elemental sustainability-related weaknesses of the existing Sirinić houses have been identified.

In terms of energy efficiency, the regeneration of Sirinić houses should aim to upgrade encountered insubstantial thermal protection and increase currently very modest use of renewable energy sources available in situ. Accordingly, the improvement of energy performance could concern intensified application of techniques for direct, indirect, or isolated passive solar gain, and the introduction of active conditioning mechanisms, next to the upgrade of the insulative properties of the envelope.

An alternative, environmentally-friendly way should be found to manage the generated waste water, thus to reduce the pollution of soil, and underground and surface water, due to the presence of old cesspools. Furthermore, the efficiency of water consumption could be increased by introducing alternative water sources, such as the rainwater, and installing efficient indoor and outdoor equipment.

Because of the current situation, it is obvious that interventions for existing structures will be extensive and the use of new materials necessary. Care should be taken to ensure that actual good quality in this domain does not become weakened by new works, and that the already installed materials are preserved to the maximum possible extent. In other words, priority should be given to the already used types or the natural materials whose ecological characteristics do not lag behind the characteristics of materials incorporated into existing Sirinić houses. Correspondingly, the application of synthetic materials for core structure, envelope and finishing surfaces should be avoided.

Based on contemporary interpretation of sustainability and its interdependence with climate resilience [9], the regeneration of Sirinić houses should also include resilience building. Taking into consideration the massive structure of existing houses and the uncertainty regarding future climate change-related manifestations at the local level, climate resilience of the traditional Sirinić architecture could possibly be formulated as a strengthened robustness. It is necessary to reduce the risk of damage from floods that have already occurred in this area in the past. Also, it is necessary to secure adequate drainage of the lots, having in mind that Sirinić houses were built on sloped terrain, as well as to keep the materialization of the open space at a minimum, as is currently the case.

To define an optimal set of regeneration-related interventions, however, it is necessary to holistically approach every house as a separate case and to conduct the corresponding multi-criteria analysis [27]. When a need for a more extensive scope of interventions can bejustified, the regeneration of traditional houses in Sirinićka Župa could possibly result in neo-vernacular architectural expression [28]. Nevertheless, the direction of regeneration will, before all else, depend on a newly assigned function of the existing traditional structures.

The regeneration of traditional houses of Sirinićka Župa should not be understood as an isolated set of interventions but an integral part of a comprehensive strategy for sustainable development of this microregion. Whereas the environmental sustainability of the existing traditional rural houses accounted for the principal subject of this research, the socio-economic sustainability of Sirinićka Župa should be considered a decisive factor in shaping the direction of their future treatment.

Sustainable development of Sirinićka Župa is encompassed by regulations, plans, and independent research. All mentioned sources foresee multifunctionality, tourism, and specialized agricultural production as the key drivers of local socio-economic sustainability. Because of the manifold existing potentials, the currently dominant sports and recreational tourism in Sirinićka Župa could in the future be supplemented with several new forms, such as wellness tourism, cultural tourism, eco-tourism, and agritourism. [29]. Here, the traditional buildings should be considered as a strength, i.e., "a major economic asset because of their potential for conversion to tourist facilities" [30] (p. 421). 
The significance of the regeneration of traditional Sirinić houses encompasses several domains, from contribution to rural socio-cultural and economic sustainability, to preservation of heritage as a universal, collective good, and to further improvement of the ecological quality of housing units and their adjustment to present standards. To initiate this multi-beneficial process, nevertheless, it is firstly necessary to develop awareness about the significance and the potential of traditional structures [30]. Subsequently, it is necessary to develop, adopt, and implement specific local regulations and strategies with the participation of local stakeholders (including dwellers, house owners, and the potential new end-users), investors, professionals, and researchers. Finally, it is important to secure sustainable maintenance as a means for the long-lasting use of the revived architectural heritage of Sirinićka Župa.

Author Contributions: Conceptualization S.K. and B.F.; Methodology S.K. and B.F.; Analyses S.K., B.F., S.K., I.N and L.F.; Resources S.K., I.N. and L.F.; Investigation: S.K., B.F., S.K., I.N. and L.F.; Writing-draft preparation S.K., S.K. and I.N.; Writing-review and editing S.K., B.F. and L.F.; Visualization S.K., I.N. and B.F.; Supervision-L.F.; Financial support acquisition B.F.

Funding: This research received no external funding.

Acknowledgments: Authors would like to acknowledge the design studio FOLIC ARCHITECTS, Belgrade, The Republic of Serbia, for financial support.

Conflicts of Interest: The authors declare no conflict of interest.

\section{References}

1. Lampietti, J.A.; Lugg, D.G.; Van der Celen, P.; Branczik, A. The Changing Face of Rural Space. Agriculture and Rural Development in the Western Balkans; The World Bank: Washington DC, USA, 2009; Available online: http://documents.worldbank.org/curated/en/431901468299121958/pdf/ 484610PUB0Rura101Official0Use0Only1.pdf (accessed on 12 July 2019).

2. Spalević, A. Mogućnosti za razvoj ruralnog područja u Republici Srbiji. Zbornik radova Geogr. Inst. Jovan Cvijić SANU 2009, 59, 133-147.

3. Kazakova, Y.; Stefanova, V. High Nature Value Farming in the Western Balkans: Current Status and Key Challenges - A Scoping Document; The European Forum on Nature Conservation and Pastoralism (EFNCP): Lampeter, UK, 2010; Available online: http://www.efncp.org/download/HNVF_SEE_v1.pdf (accessed on 16 July 2019).

4. Mitrović, M. Sela u Srbiji: Promene Strukture i Problem Održivog Razvoja; Republički zavod za statistiku: Beograd, Srbija, 2015; Available online: http://media.popispoljoprivrede.stat.rs/2015/11/Sela_u_Srbiji.pdf (accessed on 27 June 2019).

5. Kosanović, S.; Fikfak, A.; Popović, S.G. Agrarian landscape between transition and sustainability-Gračanica area case study. Agric. For. Poljopr. I Šumarstvo 2016, 62, 227-241. [CrossRef]

6. Costa, M.R.; Batista, D. The role of built rural heritage in the contemporary landscape of Central Algarve. In Recent Researches in Environmental Science and Landscaping; Burley, J., Loures, L., Panagopoulos, T., Eds.; WSEAS Press: Faro, Portugal, 2012; pp. 78-83. Available online: https://sapientia.ualg.pt/handle/10400.1/1228 (accessed on 18 July 2019).

7. Palang, H.; Printsmann, A.; Gyuro, E.K.; Urbanc, M.; Skowronek, E.; Woloszyn, W. The forgotten rural landscapes of Central and Eastern Europe. Landsc. Ecol. 2012, 21, 347-357. [CrossRef]

8. García, A.I.; Ayuga, F. Reuse of abandoned buildings and the rural landscape: The situation in Spain. T ASABE 2007, 50, 1383-1394. [CrossRef]

9. Kosanović, S.; Fikfak, A.; Folić, B. Sustainability and resilience-(In)consistencies in two design realms. In Sustainable and Resilient Building Design: Approaches, Methods and Tools; Kosanović, S., Klein, T., Konstantinou, T., Radivojević, A., Hildebrand, L., Eds.; TU Delft Open: Delft, The Netherlands, 2018; pp. 67-81.

10. Correia, M.; Dipasquale, L.; Mecca, S. VERSUS: Heritage for Tomorrow, Vernacular Knowledge for Sustainable Architecture; Firenze University Press: Firenze, Italy, 2014; 286p.

11. Salgın, B.; Bayram, Ö.F.; Akgün, A.; Agyekum, K. Sustainable features of vernacular architecture: Housing of Eastern Black Sea Region as a case study. Arts 2017, 6, 11. [CrossRef] 
12. Radivojević, A.; Blagojević, M.R.; Rajčić, A. The issue of thermal performance and protection and modernisation of traditional half-timbered (bondruk) style houses in Serbia. J. Arch. Conserv. 2014, 20, 209-225. [CrossRef]

13. Tomovska, R.; Radivojević, A. Tracing sustainable design strategies in the example of the traditional Ohrid house. J. Clean. Prod. 2017, 147, 10-24. [CrossRef]

14. Vuksanović, D.P. Tradicionalna Arhitektura Crne Gore i bioklimatizam; Zadužbina Andrejević: Beograd, Srbija, 1998; 155p.

15. Yüksek, İ.; Esin, T. Analysis of traditional rural houses in Turkey in terms of energy efficiency. Int. J. Sustain. Energy 2013, 32, 643-658. [CrossRef]

16. Anna-Maria, V. Evaluation of a sustainable Greek vernacular settlement and its landscape: Architectural typology and building physics. Build. Environ. 2009, 44, 1095-1106. [CrossRef]

17. Sahebzadeh, S.; Heidari, A.; Kamelnia, H.; Baghbani, A. Sustainability features of Iran's vernacular architecture: A comparative study between the architecture of hot-arid and hot-arid-windy regions. Sustainability 2017, 9, 749. [CrossRef]

18. Nocca, F. The role of cultural heritage in sustainable development: Multidimensional indicators as decision-making tool. Sustainability 2017, 9, 1882. [CrossRef]

19. Cvijić, J. Osnove za geografiju i geologiju Makedonije i Stare Srbije 2; Zavod za udžbenike i nastavna sredstva: Beograd, Srbija, 1996; p. 339.

20. Županić, N. Tragom za Pelazgima. Prilog Preistorijskoj Etnologiji Slovenije, Trupa Balkanskog Poluostrva; Narodna Starina: Zagreb, Hrvatska, 1922.

21. Ivanović, M. Natpisi i ornamenti na narodnim pločama, ikonama i zvonima srpskih crkava na Kosovu i Metohiji XIV-XIX/XX Vek. In Kosovsko-Metohijski Zbornik; Srpska akademija nauka i umetnosti: Beograd, Srbija, 1998; Volume 2, pp. 13-36.

22. Opštinski Razvojni Plan Štrpce. Available online: http://helvetas-ks.org/wp/wp-content/uploads/2013/08/ OP\%C5\%A0TINSKI-Razvojni-Plan-\%C5\%A0trpce.pdf (accessed on 10 June 2019).

23. Kosanović, S. Ekološki Ispravne Zgrade-Uvod u Planiranje i Projektovanje; Zadužbina Andrejević: Beograd, Srbija, 2009; 93p.

24. Gadžić, N. Architecture in Šar Mountain villages. Facta Univ. Ser. Archit. Civ. Eng. 2017, 15, $277-294$. [CrossRef]

25. Gadžić, N. Seoska arhitektura Siriničke župe. Partimonium. Mk 2016, 9, 325-334. Available online: http://www.kalamus.com.mk/pdf_spisanija/patrimonium_9/022\%20=\%20027_1\%20Nebojsa\% 20Gadzic\%20-\%20Patrimonium\%202016.pdf (accessed on 7 June 2019).

26. Babić, G. Tragom Prošlosti: Arhitektonsko i Etnografsko Istraživanje Šar Planine u delu Zorana, B. Petrovića $i$ Božidara Petrovića; Arhitektonski fakultet Univerziteta u Beogradu: Beograd, Srbija, 2011; 216p.

27. Šiožinytè, E.; Antuchevičienè, J.; Kutut, V. Upgrading the old vernacular building to contemporary norms: Multiple criteria approach. J. Civ. Eng. Manag. 2014, 20, 291-298. [CrossRef]

28. Turkušić, E. Neo-Vernacular Architecture-Contribution to the Research on Revival of Vernacular Heritage through Modern Architectural Design. In Importance of Place, Proceedings of the 4th International Conference on Hazards and Modern Heritage, Sarajevo, Bosnia and Herzegovina, 13-16 June 2011; CICOPBH: Sarajevo, Bosnia and Herzegovina, 2011; pp. 506-518.

29. Redžić, V. Selektivni oblici turizma u funkciji održivog razvoja nacionalnog parka "Šar-planina". BizInfo 2014, 5, 15-32.

30. Porto, S.M.; Leanza, P.M.; Cascone, G. Developing interpretation plans to promote traditional rural buildings as built heritage attractions. Int. J. Tour. Res. 2012, 14, 421-436. [CrossRef]

C 2019 by the authors. Licensee MDPI, Basel, Switzerland. This article is an open access article distributed under the terms and conditions of the Creative Commons Attribution (CC BY) license (http://creativecommons.org/licenses/by/4.0/). 